\title{
Penilaian Situs E-Government Dengan Metode Webqual Dan Importance Performance Analysis
}

\author{
Yudha Koessala Puja Andhika*, Dian Palupi Restuputri \\ Jurusan Teknik Industri, Universitas Muhammadiyah Malang \\ Jl. Raya Tlogomas 246 Malang 65144 Jawa Timur \\ Surel: yudhakoessala@gmail.com
}

\begin{abstract}
Lapor.go.id is a website to aspirate and complaints were easily accessible and integrated in order to increase community participation in monitoring programs and the performance of the government to implementation of public development and services. This research was descriptive quantitative approach using WEBQUAL dimensions namely usability, information, and service interaction that were assessed based on the perspective of performance and importance. Besides that, this research was conducted to investigate the user satisfaction on the website's performances. Based on the research result shows that users are satisfied with the website's performance with the satisfaction index value of $73.02 \%$. Beside that, It is known that the website's attributes of poorly performing and need to be improved are attributes related to the website's interfaces, website's competency, updated informations, detailed informations, and information that is easily understood.
\end{abstract}

Keyword: e-government, webqual, importance performance analysis, customer satisfaction index

\begin{abstract}
Abstrak
Lapor.go.id merupakan website untuk aspirasi dan pengaduan masyarakat berbasis media sosial. Website tersebut mudah diakses dan bertujuan meningkatkan partisipasi masyarakat dalam pengawasan program, kinerja pemerintah, penyelenggaraan pembangunan, dan pelayanan public. Penelitian ini merupakan penelitian kuantitatif deskriptif dengan pendekatan WEBQUAL. Dimensi WEBQUAL yang didugunakan adalah kebergunaan, kualitas informasi, dan kualitas interaksi. Penilaian WEBQUAL berdasarkan perspektif kinerja dan kepentingan. Penelitian ini juga mengukur kepuasan pengguna terhadap kinerja website. Hasil penelitian menunjukan indeks kepuasan sebesar 73,02\%. Selain itu, kinerja atribut website yang perlu diperbaiki adalah tampilan website, kompetensi website, update informasi, detail informasi, dan informasi yang mudah dipahami.
\end{abstract}

Kata Kunci: e-government, webqual, importance performance analysis, customer satisfaction index

\section{Pendahuluan}

Perkembangan dan pemanfaatan teknologi digital (electronic digital service) telah melahirkan sebuah bentuk birokrasi pemerintahan yang baru, yang di istilahkan sebagai electronic government. E-government atau biasa disingkat E-gov adalah penggunaan teknologi informasi oleh pemerintah (seperti : wide area network, internet dan mobile computing) yang memungkinkan pemerintah untuk mentransformasikan hubungan dengan masyarakat, dunia bisnis dan pihak yang berkepentingan [1]. Berdasarkan survei yang dilakukan PBB berjudul E-Government Survey (2014) yang dilansir pada artikel dalam www.cnnindonesia.com, mencatat Indonesia berada di peringkat 106 dari 193 negara di dunia. Selain itu, berdasarkan data yang diperoleh situs www.kemendagri.go.id (2013), bahwa dari 530 pemerintahan di Indonesia, terdapat 485 (92\%) situs web pemerintah yang aktif, 45 (8\%) situs web offline atau tidak 
aktif. LAPOR adalah salah satu e-government yang sedang dikembangkan ole pemerintah di Indonesia. LAPOR merupakan cikal-bakal sistem pengelolaan pengaduan pelayanan publik nasional sebagaimana diamanatkan oleh Undang-undang nomor 25 Tahun 2009 tentang pelayanan publik. Dilansir dari situs web Lapor.go.id (2013), pengguna LAPOR sudah mencapai angka 22.954 lebih pengguna dan ada lebih dari 62.527 laporan yang sudah diterima. Pengguna LAPOR diantaranya 46,6\% merupakan pihak swasta, $16,1 \%$ merupakan pihak pemerintahan, dan $37,3 \%$ sisanya merupakan pelajar serta profesi lainnya.

Menurut Pratama (2014), tujuan dari diterapkannya E-government di pemerintahan Indonesia adalah meningkatkan kualitas dan kuantitas layanan masyarakat berbasis teknologi informasi, mendukung terjadinya proses pemerintahan yang bersih dan transparan, dan membantu perbaikan sistem dalam organisasi pemerintahan. Hal tersebut menyebabkan E-government atau pemerintahan berbasis elektronik semakin berperan penting bagi semua pengambilan keputusan. Sedangkan pemerintah tradisional yang identik dengan administrasi menggunakan kertas mulai ditinggalkan. Karena penelitian mengenai E-government masih sangat sedikit di Indonesia, maka hal itulah yang menjadikan peneliti tertarik untuk mengangkat penelitan mengenai penilaian situs pemerintah Lapor.go.id, selain itu banyaknya keluhan serta rumitnya sistem birokrasi dalam melakukan pengaduan serta peayanan keluhan di Indonesia juga merupakan alasan peneliti melakukan penelitian terhadap Lapor.go.id.

Menurut penelitian yang dilakukan oleh DeLone dan McLean (2003) menyimpulkan bahwa kualitas informasi dan kualitas pelayanan berpengaruh positif terhadap tingkat kepuasan pengguna dan intensitas penggunaan layanan suatu sistem informasi. Oleh karena itu, pada penelitian ini dilakukan penilaian terhadap situs Lapor.go.id dengan menggunakan metode webqual dan importance performance analysis (IPA). Webqual digunakan untuk menilai situs tersebut berdasarkan atribut dan nilai skala likert's [2] sedangkan importance performance analysis digunakan untuk mengetahui prioritas setiap atribut. Penilaian pengguna dalam penelitian ini dibedakan ke dalam dua perspektif yaitu penilaian terhadap tingkat kinerja dan tingkat kepentingan. Dari penilaian terhadap masing-masing atribut kualitas situs tersebut, dapat dilihat indikator kualitas mana saja yang telah sesuai dengan keinginan pengguna dan mana saja yang membutuhkan perbaikan.

\section{Metode Penelitian}

Menurut Pratama (2014:442) E-government merupakan upaya dan proses yang dilakukan oleh pemerintah untuk mengimplemetasikan pemanfaatan komputer, jaringan komputer, dan teknologi informasi untuk menjalankan pemerintahan dan pelayanan publik. Bentuk pelayanan publik ini mencakup segala kegiatan administrasi kependudukan, pemerintahan, informasi masyarakat, berbasis komputer.

Penelitian ini dilakukan menggunakan kuesioner webqual. Menurut Barnes dan Vidgen (barnes) dalam jurnalnya mengatakan Webqual merupakan salah satu metode atau teknik pengukuran kualitas website berdasarkan persepsi pengguna akhir. Versi pertama dari Webqual 1.0 dikembangkan sebagai bagian dari hasil lokakarya yang diselenggarakan dengan melibatkan para siswa yang diminta untuk mempertimbangkan kualitas website sekolah. Instrument Webqual disaring melalui proses perbaikan secara iteratif dengan menggunakan kuesioner percobaan sebelum disebarkan untuk populasi yang lebih besar. 23 pertanyaan di dalam Webqual diuji dengan aplikasi dalam ruang lingkup website sekolah bisnis di Inggris. Analisis dari 
data yang dikumpulkan mendorong penghapusan atas satu item pertanyaan. Berdasarkan analisis reliabilitas, 22 pertanyaan yang kemudian dikelompokkan menjadi 3 dimensi utama yaitu kemudahan penggunaan, pengalaman, dan informasi, komunikasi.Kualitas yang didefinisikan dalam Webqual 1.0 membentuk titik awal untuk menilai kualitas informasi dari suatu website di Webqual 2.0. Semua kualitas dapat dikategorikan menjadi 3 wilayah yang berbeda yaitu kualitas website, kualitas informasi, dan kualitas interaksi pelayanan. Versi baru Webqual 3.0 telah diuji dalam domain lelang online. Analisa lanjutan terhadap Webqual 3.0 menghasilkan pendekatan model Webqual 4.0 yang akhirnya mengganti dimensi pertama, yaitu kualitas situs menjadi dimensi kebergunaan (usability). (barnes)

Berikut penjabaran dimensi beserta indikator yang dihasilkan dari teori Webqual 4.0 (barnes) [3]

Tabel 1 Indikator Webqual 4.0

\begin{tabular}{l|l}
\hline \multicolumn{1}{c|}{ Dimensi } & \multicolumn{1}{c}{ Deskripsi Indikator } \\
\hline Kebergunaan (usability) & $\begin{array}{l}\text { 1. Website mudah untuk dioperasikan. } \\
\text { 2. Interaksi dengan website mudah dan cepat. } \\
\text { 3. Website mudah untuk bernavigasi. } \\
\text { 4. Website mudah untuk digunakan. } \\
\text { 5. Tampilan Website menarik. } \\
\text { 6. Desain sesuai dengan jenis website. } \\
\text { 7. Website mengandung kompetensi atau pembelajaran. } \\
\text { 8. Website memberikan pengalaman positif bagi pengguna. }\end{array}$ \\
\hline Kualitas Informasi & $\begin{array}{l}\text { 9. Website menyediakan informasi yang akurat. } \\
\text { 10. Website menyediakan informasi yang dapat dipercaya. }\end{array}$ \\
$\begin{array}{l}\text { 11. Website menyediakan informasi yang up to date. } \\
\text { 12. Website menyediakan informasi yang relevan. }\end{array}$ \\
$\begin{array}{l}\text { 13. Website menyediakan informasi yang mudah dipahami. } \\
\text { 14. Website menyediakan informasi yang cukup detail. } \\
\text { 15. Website menyediakan informasi dalam format yang sesuai. }\end{array}$ \\
$\begin{array}{l}\text { 16. Website mempunyai reputasi yang baik. } \\
\text { 17. Pengguna mendapatkan keamanan untuk melakukan } \\
\text { transaksi. } \\
\text { 18. Pengguna merasa aman dalam menyampaikan data } \\
\text { pribadi. } \\
\text { 19. Dapat melakukan personalisasi dalam website. } \\
\text { 20. Website memberikan ruang untuk komunitas. } \\
\text { 21. Kemudahan untuk memberi feedback terhadap pengelola. } \\
\text { 22. Pengguna memiliki kepercayaan yang tinggi atas informasi } \\
\text { yang disampaikan website. }\end{array}$ \\
\hline
\end{tabular}

Sumber: Barnes dan Vidgen (2003)

Hasil dari pengumpulan data berdasarkan metode webqual kemudian dilakukan uji validitas dan reliabilitas. Menurut Priyatno (2014:51) uji validitas merupakan uji instrumen data untuk mengetahui seberapa cermat suatu item dalam mengukur apa yang ingin diukur. Item dapat dikatakan valid jika adanya korelasi yang signifikan dengan skor totalnya, hal ini menunjukkan adanya dukungan item tersebut dalam mengungkap suatu yang diungkap. Item biasanya berupa petanyaan atau pernyataan yang ditujukan kepada responden dengan menggunakan bentuk kuesioner. Sedangkan 
uji reliabiltas digunakan untuk mengetahui konsistensi alat ukur yang biasanya menggunakan kuesioner. Uji reliabilitas merupakan kelanjutan dari uji validitas, dimana item yang masuk pengujian adlaah item yang valid saja.

Pada penelitian ini juga ingin mengetahui hubungan antara tingkat kinerja terhadap kepuasan dengan menggunakan metode regresi linier berganda. Menurut Priyatno (2014), regresi linier berganda adalah regresi yang melibatkan hubungan antara satu variabel tak bebas (dependen) dengan dua atau lebih variabel bebas (independen). Bentuk umum persamaan regresi linier berganda adalah:

$$
\begin{aligned}
\mathrm{y}=\mathrm{a}+ & \mathrm{b} 1 \mathrm{X} 1+\mathrm{b} 2 \mathrm{X} 2+\ldots \ldots .+\mathrm{bnXn}(1) \\
& \text { Dimana: } \\
\mathrm{y} & =\text { variabel dependen } \\
\mathrm{a} & =\text { titik potong kurva terhadap sumbu } \mathrm{y} \\
\mathrm{b} & =\text { kemiringan kurva linier } \\
\mathrm{x} & =\text { variabel bebas (independen) } \\
\mathrm{n} & =\text { jumlah variabel bebas }
\end{aligned}
$$

Kemudian untuk mengetahui tingkat kepuasan yang diterima pengguna terhadap kinerja situs digunakan metode customer satisfaction index (CSI). CSI (Customer Satisfaction Index) digunakan untuk mengetahui tingkat kepuasan pelanggan secara menyeluruh dengan melihat tingkat kepentingan dari produk-produk layanan. $[4,5]$

Model importance performance analysis (IPA) digunakan untuk mengukur kinerja kepuasan yang dianggap penting oleh pelanggan dan kinerja kepuasan yang diterima oleh pelanggan[6]. Tujuan utama IPA adalah sebagai alat mendiagnostik untuk memudahkan mengidentifikasi atribut-atribut, yang didasarkan pada kepentingannya masing-masing[7]. Tahapan pertama dalam metode IPA yaitu menentukan tingkat kesesuaian antara tingkat kepentingan dan tingkat kinerja kualitas atribut-atribut yang diteliti melalui perbandingan skor kinerja dengan skor kepentingan. Diagram kartesius model importance performance analysis (IPA) seperti terlihat pada gambar 1. [8]

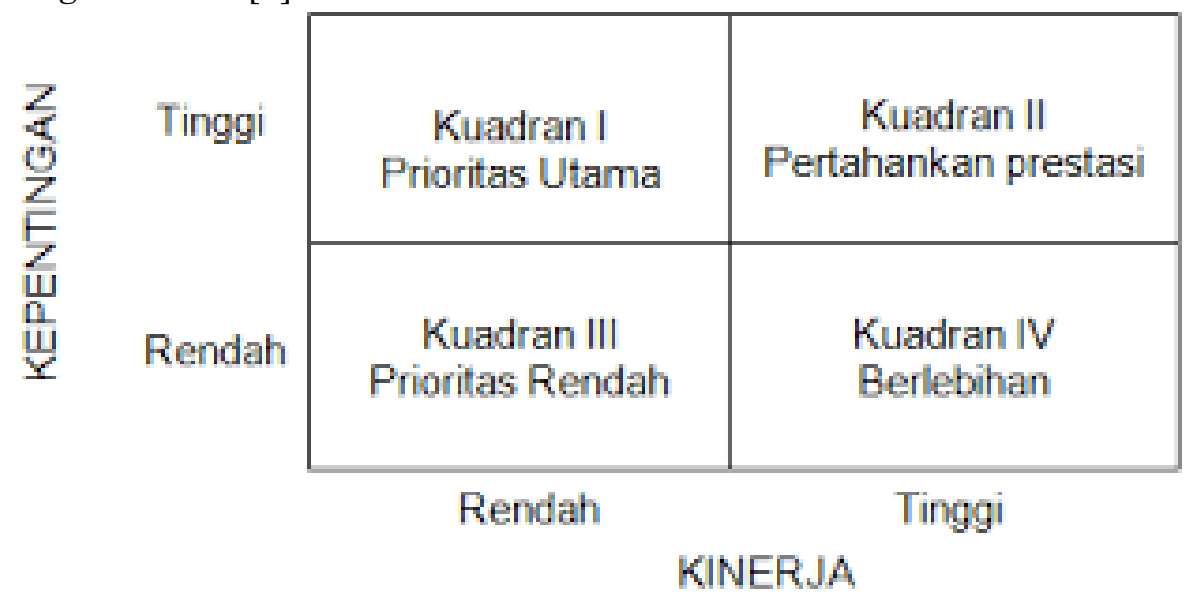

Gambar 1. Diagram Importance Performance Analysis (IPA)

\section{Hasil dan Pembahasan}

\subsection{Uji Validitas dan Reliabilitas Pengumpulan Data Tahap 1}

Pengumpulan data tahap 1 dilakukan terhadap 30 responden, hanya untuk mengetahui kevalidan dan kehandalan kuesioner untuk penelitian. Uji validitas 
dilakukan terhadap dua aspek kuesioner yang sudah ditentukan dengan menggunakan metode korelasi pearson, dimana korelasi pearson ini mengukur adanya hubungan linier antar atribut. Hasil dari uji validitas dapat dilihat pada tabel 2 dan 3.

Tabel 2 Uji Validitas Kuisioner Tingkat Kinerja

\begin{tabular}{ccccc}
\hline \multirow{2}{*}{ Dimensi } & Atribut & \multicolumn{3}{c}{ Aspek Tingkat Kinerja } \\
\cline { 3 - 5 } & & r Hitung & r Tabel & Keterangan \\
\hline \multirow{4}{*}{ Kebergunaan (usability) } & Atribut 1 & 0.4 & 0.361 & Valid \\
& Atribut 2 & 0.428 & 0.361 & Valid \\
& Atribut 3 & 0.511 & 0.361 & Valid \\
& Atribut 4 & 0.453 & 0.361 & Valid \\
& Atribut 5 & 0.556 & 0.361 & Valid \\
& Atribut 6 & 0.607 & 0.361 & Valid \\
& Atribut 7 & 0.433 & 0.361 & Valid \\
\hline \multirow{5}{*}{ Kualitas Informasi } & Atribut 8 & 0.503 & 0.361 & Valid \\
& Atribut 9 & 0.374 & 0.361 & Valid \\
& Atribut 10 & 0.568 & 0.361 & Valid \\
& Atribut 11 & 0.596 & 0.361 & Valid \\
& Atribut 12 & 0.445 & 0.361 & Valid \\
& Atribut 13 & 0.37 & 0.361 & Valid \\
& Atribut 14 & 0.487 & 0.361 & Valid \\
\hline \multirow{2}{*}{ Kualitas Interaksi } & Atribut 15 & 0.55 & 0.361 & Valid \\
& Atribut 16 & 0.566 & 0.361 & Valid \\
\hline
\end{tabular}

Tabel 3 Uji Validitas Kuisioner Tingkat Kinerja

\begin{tabular}{ccccc}
\hline \multirow{2}{*}{ Dimensi } & Atribut & \multicolumn{3}{c}{ Aspek Tingkat Kepentingan } \\
\cline { 3 - 5 } & & r Hitung & r Tabel & Keterangan \\
\hline \multirow{5}{*}{ Kebergunaan (usability) } & Atribut 1 & 0.566 & 0.361 & Valid \\
& Atribut 2 & 0.364 & 0.361 & Valid \\
& Atribut 3 & 0.579 & 0.361 & Valid \\
& Atribut 4 & 0.721 & 0.361 & Valid \\
& Atribut 5 & 0.333 & 0.361 & Valid \\
& Atribut 6 & 0.56 & 0.361 & Valid \\
& Atribut 7 & 0.624 & 0.361 & Valid \\
\hline \multirow{5}{*}{ Kualitas Informasi } & Atribut 8 & 0.602 & 0.361 & Valid \\
& Atribut 9 & 0.577 & 0.361 & Valid \\
& Atribut 10 & 0.444 & 0.361 & Valid \\
& Atribut 11 & 0.452 & 0.361 & Valid \\
& Atribut 12 & 0.44 & 0.361 & Valid \\
& Atribut 13 & 0.414 & 0.361 & Valid \\
& Atribut 14 & 0.584 & 0.361 & Valid \\
\hline \multirow{2}{*}{ Kualitas Interaksi } & Atribut 15 & 0.682 & 0.361 & Valid \\
& Atribut 16 & 0.53 & 0.361 & Valid \\
\hline
\end{tabular}

Berdasarkan hasil uji validitas diketahui bahwa tiap atribut pada aspek tingkat kinerja dan tingkat kepentingan dinyatakan valid dan dapat digunakan pada penelitian. Apabila semua atribut telah dinyatakan valid, maka kemudian dilakukan uji reliabilitas yang hasilnya dapat dilihat pada tabel 4.

Tabel 4 Uji Reliabilitas 


\begin{tabular}{cc}
\hline Aspek & Nilai Cronbach Alpha \\
\hline Tingkat Kinerja & 0.788 \\
Tingkat Kepentingan & 0.835 \\
\hline
\end{tabular}

Berdasarkan hasil uji reliabilitas tersebut, dinyatakan bahwa kuesioner tingkat kinerja dan tingkat kepentingan sudah dinyatakan reliable atau sudah handal.

\subsection{Penentuan Sampel}

Penentuan jumlah sampel dilakukan untuk menghitung jumlah sampel minimum yang dibutuhkan dalam penelitian ini. Penentuan jumlah sampel pada penelitian ini menggunakan rumus Bernoulli.

Perhitungan dengan rumus Bernoulli:

$$
\begin{aligned}
& n=\frac{\left(z^{\alpha} / 2\right)^{2} * P * Q}{e^{2}} \\
& n=\frac{(1.96)^{2} * 0.867 * 0.133}{0.1^{2}} \\
& n \geq 45
\end{aligned}
$$

Berdasarkan nilai $\mathrm{n}$ yang sudah didapatkan, maka diketahui bahwa jumlah sampel minimum yang harus dipenuhi adalah lebih dari atau sama dengan 45 sampel sehingga pada pengumpulan data tahap 2 harus mengumpulkan sampel atau responden sejumlah 45 sampel.

\subsection{Analisis Pengaruh Tingkat Kinerja Terhadap Tingkat Kepuasan Berdasarkan Persepsi Pengguna}

Data yang diinputkan pada analisis regresi ini adalah data hasil kuesioner tingkat kinerja mulai dari atribut 1 hingga atribut 16 dan juga data hasil kuesioner tingkat kepuasan oleh 45 responden.. Hasil uji regresi linier berganda dapat dilihat pada gambar 2 dan 3 .

ANOVA $^{\mathrm{a}}$

\begin{tabular}{|ll|r|r|r|r|r|}
\hline Model & & $\begin{array}{l}\text { Sum of } \\
\text { Squares }\end{array}$ & df & Mean Square & F & Sig. \\
\hline 1 & Regression & .137 & 3 & .046 & 3.348 & $.386^{{ }^{\mathrm{b}}}$ \\
& Residual & 38.742 & 41 & .945 & & \\
& Total & 38.880 & 44 & & & \\
\hline
\end{tabular}

a. Dependent Variable: KepuasanPengguna

b. Predictors: (Constant), KualitasInteraksi, Kebergunaan, KualitasInformasi

Gambar 2 Output Hasil Uji Anova

Dari hasil output diatas dinyatakan bahwa $\mathrm{F}$ hitung $>\mathrm{F}$ tabel $(3,348>3,22)$, maka dinyatakan bahwa 3 dimensi tersebut secara bersama-sama berpengaruh terhadap kepuasan pengguna. 


\begin{tabular}{|c|c|c|c|c|c|c|c|c|}
\hline \multicolumn{9}{|c|}{ Coefficients $^{2}$} \\
\hline \multirow{2}{*}{\multicolumn{2}{|c|}{ Model }} & \multicolumn{2}{|c|}{ Unstandardized Coefficients } & \multirow{2}{*}{$\begin{array}{c}\text { Standardized } \\
\text { Coefficients } \\
\text { Beta }\end{array}$} & \multirow[b]{2}{*}{$t$} & \multirow[b]{2}{*}{ Sig. } & \multicolumn{2}{|c|}{ Collinearity Statistics } \\
\hline & & B & Std. Error & & & & Tolerance & VF \\
\hline \multirow[t]{4}{*}{1} & (Constant) & 4.298 & 2.787 & & 1.542 & .131 & & \\
\hline & Kebergunaan & .057 & .385 & .023 & 2.147 & .584 & .997 & 1.003 \\
\hline & KualitasInformasi & .105 & .517 & .032 & 2.204 & .539 & .982 & 1.019 \\
\hline & Kualitasinteraksi & .072 & 235 & .048 & 2.308 & 360 & 982 & 1.019 \\
\hline
\end{tabular}

a. Dependent Variable: KepuasanPengguna

Gambar 3. Output Hasil Uji t

Berdasarkan hasil output tersebut, maka diketahui dimensi yang berpengaruh secara parsial terhadap kepuasan pengguna atau H0 ditolak adalah adalah ketiga dimensi yaitu dimensi kebergunaan, kualitas informasi, dan kualitas interaksi.

\subsection{Customer Satisfaction Index (CSI)}

Selain menilai secara langsung mengenai kepuasan pengguna terhadap kinerja situs, penelitian ini juga menghitung kepuasan dengan mengan menggunakan metode customer satisfaction index (CSI). Customer satisfaction index dgunakan untuk menilai atau menghitung tingkat kepuasan pengguna terhadap kinerja dari keseluruhan situs lapor.go.id tersebut. Tingkat kepuasan dibawah 20\% menyatakan bahwa pengguna tidak puas, $21 \%-40 \%$ menyatakan bahwa pengguna kurang puas, $41 \%-60 \%$ menyatakan bahwa pengguna cukup puas, $61 \%-80 \%$ menyatakan bahwa pengguna puas terhadap situs, dan apabila tingkat kepuasan lebih dari 80\%, maka pengguna situs dinyatakan sangat puas terhadap situs lapor.go.id.

Berdasarkan hasil perhitungan customer satisfaction index didapatkan bahwa nilai customer satisfaction index adalah sebesar $73,02 \%$ yang artinya pengguna situs lapor.go.id merasa puas terhadap kualitas situs tersebut.

\subsection{Importance Performance Analysis (IPA)}

Tingkat kesesuaian merupakan hasil perbandingan antara menghitung skor kinerja dengan skor kepentingan, sehingga tingkat kesesuaian ini yang digunakan untuk menentukan skala prioritas atribut kualitas dan prioritas perbaikan untuk mencapai kepuasan pengguna[9]. Jika persentase 80-100\% maka kesesuaian tersebut dapat dikatakan kinerja telah dapat memenuhi kepentingan dari pengguna tetapi masih perlu dilakukan perbaikan. Sedangkan jika persentase $>100 \%$ maka dapat dikatakan kinerja dari atribut tersebut dinilai pengguna sudah sesuai dengan kepentingan mereka[10]. Hasil perhitungan tingkat kesesuaian dapat dilihat pada tabel 5 .

Berdasarkan hasil tingkat kesesuaian diatas diketahui bahwa atribut yang paling sesuai antara tingkat kinerja dengan tingkat kepentingannya adalah atribut 5 dan atribut 1 yaitu desain sesuai dengan jenis situs dan situs mudah dioperasikan.

Data rata-rata tiap atribut pada tingkat kinerja (X) dan tingkat kepentingan (Y) kemudian dijabarkan ke dalam diagram kartesius, sehingga akan diketahui letak kuadran dari masing-masing atribut tersebut. Hasil Diagram kartesius dapat dilihat pada gambar 4 . 
Tabel 5 Tingkat Kesesuaian Tingkat Kinerja dan Tingkat Kepentingan

\begin{tabular}{ccc} 
Dimensi & Atribut & Tingkat Kesesuaian \\
\hline \multirow{3}{*}{ Kebergunaan (usability) } & Atribut 1 & $123.31 \%$ \\
& Atribut 2 & $105.92 \%$ \\
& Atribut 3 & $100.00 \%$ \\
& Atribut 4 & $105.59 \%$ \\
& Atribut 5 & $123.94 \%$ \\
& Atribut 6 & $106.61 \%$ \\
& Atribut 7 & $110.91 \%$ \\
\hline \multirow{2}{*}{ Kualitas Informasi } & Atribut 8 & $110.61 \%$ \\
& Atribut 9 & $103.10 \%$ \\
& Atribut 10 & $99.29 \%$ \\
& Atribut 11 & $86.59 \%$ \\
& Atribut 12 & $115.58 \%$ \\
& Atribut 13 & $116.78 \%$ \\
& Atribut 14 & $77.01 \%$ \\
\hline \multirow{2}{*}{ Kualitas Interaksi } & Atribut 15 & $87.92 \%$ \\
& Atribut 16 & $92.25 \%$ \\
\hline \multirow{2}{*}{} &
\end{tabular}

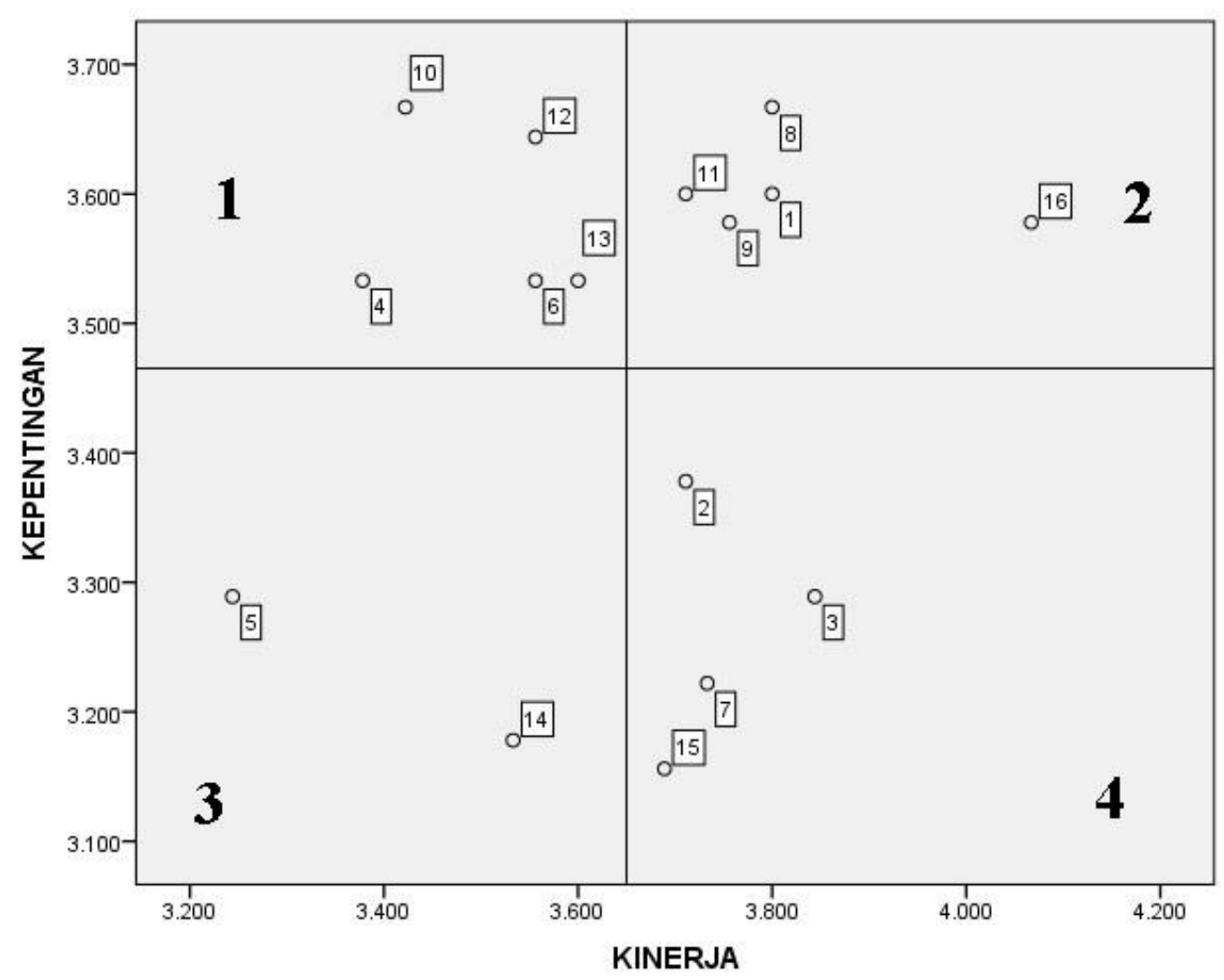

Gambar 4. Diagram Kartesius Importance Performance Analysis (IPA)

\section{Simpulan}

Dari analisis pengaruh dimensi tingkat kinerja terhadap tingkat kepuasan pengguna diketahui bahwa dimensi kebergunaan, kualitas informasi, dan kualitas interaksi, ketiganya berpengaruh secara parsial terhadap tingkat kepuasan pengguna situs Lapor.go.id. Dengan melihat hasil perhitungan customer satisfaction index (CSI), 
diketahui bahwa tingkat kepuasan yang diterima pengguna situs lapor.go.id adalah sebesar $73,02 \%$. Nilai customer satisfaction index tersebut menyatakan bahwa pengguna sudah merasa puas terhadap kualitas situs lapor.go.id. Berdasarkan analisis importance performance analysis (IPA), terdapat 5 atribut yang dianggap penting namun kinerjanya dirasakan tidak memuaskan oleh pengguna situs. Atribut tersebut antara lain tampilan situs menarik, situs mengandung pembelajaran, situs menyediakan informasi yang update, situs menyediakan informasi yang detail, dan situs menyediakan informasi yang mudah dipahami. Dan atribut yang dinilai memiliki kinerja paling buruk berdasarkan importance performance analysis adalah atribut tampilan situs menarik, sehingga perlu diperbaiki dengan melakukan perbaikan desain pada situs seperti perbaikan pada warna, font, maupun layout.

\section{Referensi}

[1] N. D. Parkhurst, T. Morris, E. Tahy, and K. Mossberger, "The digital reality: egovernment and access to technology and internet for American Indian and Alaska Native populations," in Proceedings of the 16th Annual International Conference on Digital Government Research, 2015, pp. 217-229.

[2] J. Hasanov and H. Khalid, "The impact of website quality on online purchase intention of organic food in Malaysia: A webQual model approach," Procedia Computer Science, vol. 72, pp. 382-389, 2015.

[3] S. J. Barnes and R. Vidgen, "Measuring web site quality improvements: a case study of the forum on strategic management knowledge exchange," Industrial management \& Data systems, vol. 103, pp. 297-309, 2003.

[4] R. Aritonang and R. Lerbin, "Kepuasan Pelanggan. Pengukuran dan Penganalisisan dengan SPSS," Jakarta: PT. Gramedia Pustaka Utama, 2005.

[5] M. H. Askariazad and N. Babakhani, "An application of European Customer Satisfaction Index (ECSI) in business to business (B2B) context," Journal of business \& industrial marketing, vol. 30, pp. 17-31, 2015.

[6] I. Sever, "Importance-performance analysis: A valid management tool?," Tourism Management, vol. 48, pp. 43-53, 2015.

[7] I. K. W. Lai and M. Hitchcock, "Importance-performance analysis in tourism: A framework for researchers," Tourism Management, vol. 48, pp. 242-267, 2015.

[8] F. Rangkuti, "Measuring Customer Satisfaction: Gaining Customer Relation-ship Strategy (Teknik Mengukur dan Strategi Meningkatkan Kepuasan pelanggan)," Gramedia Pustaka Utama, Jakarta, 2003.

[9] N. Kahraman, "Assessing the service quality of intelligent building control systems: An importance-performance analysis," İzmir Institute of Technology, 2015.

[10] K.-Y. Chen, "Improving importance-performance analysis: The role of the zone of tolerance and competitor performance. The case of Taiwan's hot spring hotels," Tourism Management, vol. 40, pp. 260-272, 2014. 